\author{
MARIOLA JAKUBOWSKA \\ Uniwersytet Mikołaja Kopernika w Toruniu \\ m_jakubowska2@wp.pl
}

\title{
Wynagrodzenie dla zatrudnionych odbywających karę pozbawienia wolności
}

Remuneration of employees serving a sentence of imprisonment

Streszczenie. Jedną z form resocjalizacji osadzonych jest wykonywanie pracy. Wówczas, nawiązuje się charakterystyczny stosunek pracy, regulowany nie tylko przepisami prawa pracy, ale również prawem karnym wykonawczym. Niewątpliwie, wynagrodzenie stanowi ważny element powstałego stosunku pracy, głównie w kontekście jego wysokości. Nad tym zagadnieniem pochylał się również Trybunał Konstytucyjny, a wyrok Trybunału miał niebagatelne znaczenie, bowiem doprowadził do zmiany przepisów, która z kolei miała wpływ na praktykę.

Słowa kluczowe: praca; skazani; więzienie; wynagrodzenie; tło międzynarodowe.

Extract. One of the forms of resocialization prisoners is work. It establishes characteristic employment relationship governed not only by the labor law but also by execution of criminal sanctions. Undoubtedly, the remuneration is an important element of the resulting employment, mainly in the context of its height. This issue was also considered by the Constitutional Tribunal and the judgment of the Tribunal had a great importance, since has led to changes in legislation, which in turn had an impact on practice.

Keywords: work; convicted; prison; remuneration; international background.

\section{Wstęp}

Praca osoby odbywającej karę pozbawienia wolności stanowi ważne zagadnienie nie tylko dla prawa karnego wykonawczego, ale również dla prawa pracy, chociażby ze względu na wynagrodzenie. Celem niniejszego artykułu jest przedstawienie regulacji prawnej zasad wynagradzania za pracę osób odbywających karę pozbawienia wolności w świetle wyroku Trybunału Konstytucyjnego z dnia 23 lutego 2010 r. (P 20/09). Zaprezentowane zostały również międzynarodowe standardy dotyczące zasad wynagradzania osób wykonujących pracę $\mathrm{w}$ okresie odbywania kary pozbawienia wolności oraz rozwiązania w tym zakresie w wybranych państwach europejskich. 


\section{Wynagrodzenie za pracę wykonywaną w okresie odbywania kary pozbawienia wolności - międzynarodowe standardy}

Trybunał Konstytucyjny w uzasadnieniu do wyroku z dnia 23 lutego 2010 r. odwołał się do standardów międzynarodowych. Wskazał on, że określają one minimalny wzorzec humanitarnego traktowania więźniów, który powinien być przestrzegany w każdym państwie prawnym. Co więcej, stanowią także wskazówki interpretacyjne, które powinno brać się pod uwagę przy dokonywaniu wykładni prawa polskiego.

W dniach od 22 sierpnia do 3 września 1955 r. w Genewie odbył się I Kongres ONZ w sprawie Zapobiegania Przestępczości i Postępowania ze Sprawcami Przestępstw. Przyjęto wtedy Wzorcowe reguły ONZ minimum postępowania $\mathrm{z}$ więźniami. W zakresie wynagrodzenia istotne znaczenie ma reguła 71.4, w świetle której w takim stopniu jak to możliwe, zapewniona praca ma utrzymać bądź zwiększyć zdolność więźnia do uczciwego zarabiania na życie po zwolnieniu. Reguła 76.1 wyraża gwarancję systemu sprawiedliwego wynagradzania pracy więźniów. Postuluje się także, by system ten zapewniał wyodrębnienie i przechowywanie przez administrację instytucji części zarobków, tak aby stanowiły fundusz, który zostanie przekazany więźniowi w chwili jego zwolnienia. Co najmniej część swoich zarobków więźniowie mogą przeznaczyć na zakup dozwolonych artykułów użytku osobistego oraz mogą wysyłać części tych zarobków własnej rodzinie (reguła 76.2). Komentarz do Wzorcowych reguł minimum postępowania z więźniami wskazuje, że jeśli minimalne wynagrodzenie funkcjonuje $\mathrm{w}$ społeczeństwie, powinno zatem znaleźć odzwierciedlenie w zarobkach więźniów ${ }^{1}$.

Dnia 11 stycznia 2006 r. Komitet Ministrów Rady Europy przyjął Europejskie Reguły Więzienne $^{2}$. Zgodnie z regułą 105.3, jeśli więźniowie skazani są zobowiązani do pracy, to jej warunki mają obowiązek odpowiadać standardom i kontroli stosowanej w społeczeństwie otwartym. W regule 26.3 zaleca się, by tak dalece jak to możliwe, praca przydzielana więźniom przyczyniała się do podtrzymania lub rozwoju ich zdolności do zarabiania na życie po zwolnieniu. Więźniowie powinni mieć możliwość przeznaczenia przynajmniej części swojego wynagrodzenia na zakup przedmiotów osobistego użytku albo wysyłanie zarobków rodzinie (reguła 26.11). Można zachęcać więźniów do częściowego oszczędzania wynagrodzenia i powinni oni mieć możliwość odzyskania tej części po zwolnieniu

\footnotetext{
1 E. Dawidziuk, Traktowanie osób pozbawionych wolności we współczesnej Polsce na tle standardów międzynarodowych, Warszawa 2013, s. 178.

${ }^{2}$ http://www.cossw.pl/file/redir.php?id=5853 [dostęp: 27.10 .2015 r.].
} 
z więzienia lub przeznaczenia jej na inne dozwolone cele (reguła 26.12). Reguła 26.10 wyraża zapewnienie sprawiedliwego wynagrodzenia za pracę więźniów w każdym przypadku.

Rezolucja Komitetu Ministrów Rady Europy z dnia 18 września 1975 r. w sprawie pracy więziennej zaleca przyjęcie warunków pracy oraz wynagrodzenia porównywalnego do standardów zewnętrznych tak dalece, jak to jest możliwe do zrealizowania, biorąc pod uwagę specyficzną naturę pracy w więzieniu.

Warto odwołać się także do Powszechnej deklaracji praw człowieka, która w art. 23 ust. 2 stanowi, że każdy człowiek, bez względu na jakiekolwiek różnice, ma prawo do równej płacy za równą pracę, a w ust. 3, że każdy pracujący ma prawo do odpowiedniego i zadowalającego wynagrodzenia, zapewniającego jemu i jego rodzinie egzystencję odpowiadającą godności ludzkiej i uzupełnianego w razie potrzeby innymi środkami pomocy społecznej.

Ponadto, Polska jako strona Międzynarodowego paktu praw gospodarczych, społecznych i kulturalnych jest zobowiązana do uznania praw każdego do korzystania ze sprawiedliwych i korzystnych warunków pracy, obejmujących w szczególności wynagrodzenie zapewniające wszystkim pracującym jako minimum godziwy zarobek i równe wynagrodzenie za pracę o równej wartości, bez jakiejkolwiek różnicy.

3. Odpłatność w przypadku wykonywania pracy przez osoby odbywające karę pozbawienia wolności w Polsce

3.1. Uwagi ogólne. Odpłatne wykonywanie pracy w okresie odbywania kary pozbawienia wolności

Zgodnie z ustawą o zatrudnieniu osób pozbawionych wolności (dalej u.z.o.p.) osiąganie zysku powinno być podporządkowane resocjalizacji ${ }^{3}$. Co do zasady skazany pracuje odpłatnie z wyjątkiem prac porządkowych, pomocniczych wykonywanych na rzecz jednostek organizacyjnych Służby Więziennej albo prac porządkowych na rzecz samorządu terytorialnego, których wymiar nie przekracza 90 godzin miesięcznie albo w celu przyuczenia do wykonywania pracy w przywięziennych zakładach pracy, za pisemną zgodą skazanego, przez okres nie dłuższy niż 1 miesiąc ${ }^{4}$. Skazany może być zatrudniony odpłatnie przy pracach porządkowych oraz pomocniczych na rzecz jednostek organizacyjnych Służby Więziennej w wymiarze przekraczającym 90 godzin, w przywięziennych zakładach pracy lub u innych zewnętrznych przedsiębiorców, w tym również w ramach umowy o pracę, umowy zlecenia,

\footnotetext{
${ }^{3}$ Ustawa z dnia 28 sierpnia 1997 r. o zatrudnianiu osób pozbawionych wolności (tekst jednolity Dz. U. z 2014 r., poz. 1116), art. 1 ust. 2., art. 1 ust. 2.

${ }^{4}$ Ustawa z dnia 6 czerwca 1997 r. Kodeks karny wykonawczy (Dz. U. z 1997 r. Nr 90 poz. 557 ze zm., dalej jako: k.k.w.), art. 123, 123a.
} 
umowy o dzieło lub umowy o pracę nakładczą ${ }^{5}$ Zasada odpłatności odnosi się do wszystkich rodzajów zatrudnienia skazanych, niezależnie od podstawy prawnej, co w konsekwencji powinno oznaczać dla skazanego wymierne korzyści ${ }^{6}$.

Porozumienie zawierane przez dyrektora zakładu karnego lub umowa zawierana przez skazanego zawiera ustalenia dotyczące zasad wynagradzania ${ }^{7}$. Przy skierowaniu skazanego do prac administracyjno-porządkowych na terenie zakładu karnego wynagrodzenie za pracę ustala dyrektor tego zakładu. Wynagrodzeniem skazanego jest kwota przypadająca mu po dokonaniu potrąceń, tj. składek na ubezpieczenie społeczne, kwoty na Fundusz Pomocy Pokrzywdzonym oraz Pomocy Postpenitencjarnej i kwoty na Fundusz Aktywizacji Zawodowej Skazanych oraz Rozwoju Przywięziennych Zakładów Pracy, stanowiąca podstawę do naliczenia zaliczki na podatek dochodowy od osób fizycznych ${ }^{8}$. Na pierwszy z funduszy potrąca się $10 \%$ wynagrodzenia, na drugi $25 \%$. Z przypadającego skazanemu wynagrodzenia za pracę, po odliczeniu zaliczki na podatek dochodowy od osób fizycznych, wolne od egzekucji jest $60 \%$ wynagrodzenia ${ }^{9}$. Podstawą do naliczenia zaliczki na podatek dochodowy od osób fizycznych jest kwota pozostała po odliczeniu składek na ubezpieczenia społeczne i wymienione fundusze. Zgodnie z art. 126 \$2 pkt 2 k.k.w.: ,gromadzeniu podlega $50 \%$ z przypadającego skazanemu miesięcznie wynagrodzenia za pracę po odliczeniu zaliczki na podatek dochodowy od osób fizycznych, jednak nie więcej niż kwota $4 \%$ jednego przeciętnego miesięcznego wynagrodzenia pracowników". Zakład karny gromadzi te pieniądze, ale w chwili opuszczenia zakładu karnego przez skazanego wypłaca mu te środki.

\subsection{Wyrok Trybunalu Konstytucyjnego z dnia 3 lutego 2010 r. (P 20/09)}

Niebagatelne znaczenie dla omawianego zagadnienia ma wcześniej wspomniany wyrok Trybunału Konstytucyjnego. Obowiązujący wówczas art. 123 §2 $\quad$ k.k.w. ograniczał wynagrodzenie przysługujące skazanemu zatrudnionemu w pełnym wymiarze czasu pracy do co najmniej połowy minimalnego wynagrodzenia określonego na podstawie odrębnych przepisów, przy przepracowaniu pełnego miesięcznego wymiaru czasu pracy lub wykonaniu miesięcznej normy pracy. Regulacja ta była krytykowana, gdyż mogła powodować wyzysk więźniów, jak również stwarzała warunki do organizowania niewolniczej pracy. Choć zaletą

\footnotetext{
${ }^{5}$ Rozporządzenie Ministra Sprawiedliwości z dnia 9 lutego 2004 r. w sprawie szczegółowych zasad zatrudniania skazanych (tekst jednolity Dz. U. z 2004 r. nr 27, poz. 242 ze zm.).

${ }^{6}$ E. Dawidziuk, Traktowanie osób pozbawionych wolności we współczesnej Polsce na tle standardów międzynarodowych, Warszawa 2013, s. 162.

7 J. Świątek-Rudoman, Praca osób pozbawionych wolności - wybrane zagadnienia z zakresu prawa pracy i prawa penitencjarnego, „Gdańskie Studia Prawnicze”, T. XXX. Wybrane zagadnienia prawa pracy i prawa socjalnego, red. J. Stelina, Gdańsk 2013, s. 178.

${ }^{8}$ Zob. art. $242 \S 15$ k.k.w.

${ }^{9}$ Zob. art. 125 k.k.w.
} 
tego rozwiązania były większe szanse na zatrudnienie osób pozbawionych wolności, to jednak nie spełniało swojej funkcji, ponieważ było wysoce prawdopodobne, że skazani nie będą w stanie wypełniać swoich zobowiązań, np. alimentacyjnych. Trybunał Konstytucyjny orzekł, że przepis art. $123 \S 2 \mathrm{w}$ zakresie, w jakim zawiera słowo ,połowy” jest niezgodny z art. 32 oraz z art. 65 ust. 4 w związku z art. 2 Konstytucji Rzeczypospolitej Polskiej.

Wydaje się, że należy rozpocząć od podstawowego zagadnienia, jakim jest zgodność norm prawnych $\mathrm{z}$ zasadami zawartymi w Konstytucji RP. W ocenie Trybunału Konstytucyjnego przepis narusza konstytucyjną zasadę równości, wyrażoną w art. 3 ust. 1 Konstytucji. $Z$ tą zasadą bowiem wiąże się nakaz jednakowego traktowania podmiotów prawa w obrębie określonej klasy. Równość oznacza brak różnic, tak dyskryminujących jak i faworyzujących. Odstępstwo od zasady równości jest dopuszczalne przy łącznym spełnieniu następujących warunków: kryterium różnicowania pozostaje w racjonalnym związku z celem i treścią danej regulacji; waga interesu, któremu różnicowanie ma służyć, pozostaje w odpowiedniej proporcji do wagi interesów, które zostaną naruszone w wyniku wprowadzonego różnicowania a kryterium różnicowania pozostaje $\mathrm{w}$ związku z innymi wartościami, zasadami czy normami konstytucyjnymi uzasadniającymi odmienne traktowanie podmiotów podobnych. Wydaje się, że zasada równości stanowiła pewien punkt wyjścia dla rozstrzygnięcia Trybunału, co zasługuje na aprobatę. Niewątpliwie zasada ta wpływa na kształt wolności i praw każdego człowieka, a w związku z tym powinna stać na czele rozważań wątpliwych kwestii prawnych.

Jak się wydaje, drugą najważniejszą kwestią są uregulowania dotyczące wynagrodzenia zawarte w Konstytucji. Trybunał podkreślił, że Konstytucja nie stawia wymogów ustalenia minimalnego wynagrodzenia za pracę na jednakowym poziomie dla wszystkich pracowników, co dotyczy także wynagrodzenia za pracę osób skazanych. Niewątpliwie dostrzegalne są różnice między pracą osób odbywających karę pozbawienia wolności a pracą pozostałych osób. Jednakże bezsporne pozostaje to, że godność osób skazanych (także jako wykonujących pracę) podlega ochronie konstytucyjnej. Trybunał stoi na jednoznacznym stanowisku, że wszystkie osoby świadczące pracę, bez względu na jej podstawę prawną, powinny być traktowane równo w zakresie minimalnego wynagrodzenia. Nieusprawiedliwione jest zróżnicowanie osób pracujących na podstawie kryterium odbywania kary pozbawienia wolności, może bowiem prowadzić do bezpodstawnego 
zaniżania wynagrodzenia ${ }^{10}$. Chociaż rozbieżności pomiędzy wykonywaniem pracy przez osoby pozostające na wolności a osoby pozbawione wolności nie budzą żadnych wątpliwości, to jednak nie można zapominać o prawie każdej osoby do godnego traktowania. Pod tym pojęciem mieści się również otrzymywanie godziwej płacy za wykonaną pracę. Dodatkowo warto nadmienić, że zatrudnianie osób pozbawionych wolności przed orzeczeniem Trybunału i nowelizacją art. 123 k.k.w. rysowało się jako działalność opłacalna szczególnie w branży budowlanej i w przywięziennych zakładach produkcyjnych ${ }^{11}$. Dzięki regulacjom prawa podatkowego albo bodźcom finansowym dla przedsiębiorców zatrudniających osoby skazane, jest możliwość obniżenia kosztów pracy tych osób, nie obniżając tym samym ich wynagrodzenia poniżej poziomu wynagrodzenia minimalnego.

Zgodnie z art. 65 ust. 4 Konstytucji minimalną wysokość wynagrodzenia za pracę lub sposób ustalania tej wysokości określa ustawa. Obejmuje to także stosunki prawne pozostające poza tymi, które są określone w kodeksie pracy, ponieważ kodeks pracy nie może uwarunkowywać zakresu gwarancji konstytucyjnych, dotyczących praw osób wykonujących pracę zarobkową. Regulacja dotycząca wynagrodzenia minimalnego ma zagwarantować odpowiednią ochronę pracowników i musi pozostawać zgodna z zasadami sprawiedliwości społecznej. Pomimo tego, że ustawodawca ma swoistą autonomię co do ustalenia poziomu tego wynagrodzenia, nie oznacza to tym samym, że może to być regulacja dowolna. Istota instytucji minimalnego wynagrodzenia tkwi w możliwości zaspokojenia podstawowych potrzeb. Warto ponownie podkreślić, że pozbawienie osoby wolności absolutnie nie oznacza pozbawienia konstytucyjnych praw, w tym prawa do godziwego wynagrodzenia za świadczoną pracę. Zarazem Konstytucja nie wyłącza możliwości przyjęcia szczególnych rozwiązań dotyczących rozporządzania wynagrodzeniem przez osoby skazane czy też dokonania obligatoryjnych potrąceń na określone cele społeczne, o ile regulacje te będą służyć realizacji określonych wartości konstytucyjnych i pozostaną w zgodności z zasadą równości ${ }^{12}$. Konstytucja powierzyła ustawodawcy kwestie ustalenia minimalnego wynagrodzenia za pracę. Jednakże za oczywiste należy przyjąć to, że ustawowa regulacja nie może abstrahować od fundamentalnych zasad zawartych w Konstytucji.

W związku z wyrokiem Trybunału Konstytucyjnego ustawodawca znowelizował przepis art. $123 \S 2$ k.k.w. ustawą z dnia 3 lutego 2011 r. o zmianie ustawy - Kodeks karny wykonawczy oraz niektórych innych ustaw, który obecnie brzmi: „Wynagrodzenie

\footnotetext{
${ }^{10}$ Wyrok Trybunału Konstytucyjnego z dnia 23 lutego 2010 r., sygn. akt P 20/09 (Dz. U. z 2010 r. Nr 34, poz. 191).

${ }^{11}$ J. Świątek-Rudoman, Praca osób pozbawionych wolności ..., s. 178.

${ }^{12}$ Wyrok Trybunału Konstytucyjnego z dnia 23 lutego 2010 r., P 20/09 (Dz. U. z 2010 r. Nr 34, poz. 191).
} 
przysługujące skazanemu zatrudnionemu w pełnym wymiarze czasu pracy ustala się w sposób zapewniający osiągnięcie kwoty co najmniej minimalnego wynagrodzenia za pracę ustalanego na podstawie odrębnych przepisów, przy przepracowaniu pełnego miesięcznego wymiaru czasu pracy lub wykonaniu pełnej miesięcznej normy pracy.

W przypadku przepracowania niepełnej miesięcznej normy czasu pracy lub niewykonania pełnej miesięcznej normy pracy, wynagrodzenie wypłaca się proporcjonalnie do ilości czasu pracy lub wykonanej normy pracy. W razie zatrudnienia skazanego w niepełnym wymiarze czasu pracy najniższe wynagrodzenie ustala się $w$ kwocie proporcjonalnej do liczby godzin zatrudnienia, biorąc za podstawę kwotę minimalnego wynagrodzenia za pracę".

\section{Odpłatność w przypadku wykonywania pracy przez osoby odbywające karę pozbawienia wolności $w$ innych państwach}

Warto przyjrzeć się także uregulowaniom obowiązującym w innych państwach.

W Niemczech skazany otrzymuje wynagrodzenie za swoją pracę, w tym za prace pomocnicze. Wynagrodzenie bazowe wyznaczone na poziomie 9\% przeciętnego wynagrodzenia osób objętych ubezpieczeniem społecznym za poprzedni rok stanowi podstawę określenia wysokości wynagrodzenia skazanego. $Z$ tym, że wysokość wynagrodzenia skazanych może być niejednakowa ze względu na wydajność, rodzaj wykonywanej pracy i kwalifikacje zawodowe. Obniżenie wynagrodzenia bazowego może nastąpić nawet poniżej 75\% jego wysokości w razie, gdyby wydajność skazanego była poniżej wymaganego minimum ${ }^{13}$. Wydaje się, że należy pozytywnie ocenić przede wszystkim rozróżnienie dotyczące wysokości wynagrodzenia w zależności od wskazanych wyżej kryteriów. Ponadto warto podkreślić, że pośrednio skazany zobligowany jest do pracy wydajnej, w przeciwnym razie wysokość wynagrodzenia może się znacznie zmniejszyć.

W Szwecji skazany otrzymuje wynagrodzenie za wykonaną pracę w oparciu o normy ustalone przez rząd lub inny powołany organ, o ile skazany nie pracował na rachunek własny lub u pracodawcy spoza zakładu (wtedy otrzymuje wynagrodzenie jak w warunkach wolnościowych). Jeżeli skazany $\mathrm{w}$ godzinach pracy uczestniczy $\mathrm{w}$ zajęciach szkolnych, szkoleniu zawodowym lub gdy uczy się samodzielnie, także otrzymuje wynagrodzenie. Wypłatę zapewnia się także skazanemu, który z przyczyn niezależnych od siebie nie może otrzymać żadnej pracy ani brać udziału w zajęciach. Wysokość płacy zależy od wysiłku

\footnotetext{
${ }^{13}$ T. Kalisz, Zatrudnienie skazanych odbywających karę pozbawienia wolności, Wrocław 2004, s. 59.
} 
wkładanego w jej wykonywanie, chyba że sprzeciwiają się temu szczególne powody ${ }^{14}$. Podobnie jak w Niemczech istotne dla wysokości wynagrodzenia jest zaangażowanie skazanego w wykonywaną pracę, co należy uznać za sprawiedliwe. Wynagrodzenie za naukę z pewnością przyczynia się do zainteresowania wśród skazanych podwyższaniem poziomu swoich kwalifikacji. W dalszej perspektywie powinno to mieć też korzystny wpływ na jakość wykonywanej przez nich pracy.

W ustawodawstwie hiszpańskim podkreśla się, że w każdym przypadku skazany ma prawo do pracy za wynagrodzeniem. Z jednej strony mogłoby wydawać się, że to rozwiązanie z pewnością chroni skazanych przed ryzykiem niewolniczej pracy. Jednakże można mieć wątpliwości, czy rzeczywiście w każdym przypadku wynagrodzenie jest zasadne. Ocenia się to proporcjonalnie do liczby efektywnie przepracowanych godzin jak również wydajności pracy.

W Holandii ustawowo określono wynagrodzenie za pracę organizowaną przez administrację więzienną. Wynagrodzenie takie jest równe iloczynowi stawki za godzinę pracy oraz liczby efektywnie przepracowanych godzin. Dyrektor zakładu karnego jest uprawniony do przyznawania skazanym premii za pracę oraz do podwyższenia stawki za godzinę pracy. Jest to uzależnione między innymi od wydajności pracy, stopnia jej trudności czy wymaganych kwalifikacji. Przewiduje się także formę płacy minimalnej dla skazanych, którzy z przyczyn od nich niezależnych nie mogą pracować. Jeżeli niezdolność lub niemożność jest zawiniona, wtedy taka płaca nie przysługuje. Na aprobatę zasługuje regulacja zapewniająca minimum socjalne dla skazanych, którzy nie mogą podjąć pracy nie ze swojej winy.

Szwajcarski kodeks karny stanowi, że skazani otrzymują część zarobku za wykonywanie pracy, przy dobrym stosunku i zadowalającej wydajności. Wysokość płacy określa dany kanton. Uporczywe uchylanie się od zatrudnienia lub celowe spowodowanie niemożności do podjęcia pracy będzie skutkowało utratą wynagrodzenia. Niezdolny do pracy bez swojej winy lub chory skazany będzie otrzymywał odpowiednią część zarobku, określoną wewnętrznym regulaminem zakładu. W przypadku tego państwa wyraźnie zaznacza się zależność wysokości wynagrodzenia od takich czynników jak: stosunek do pracy i wydajność.

\footnotetext{
14 Tamże, s. 64.
} 
W systemie francuskim skazani za swoją pracę otrzymują różne wynagrodzenie W zależności od miejsca zatrudnienia, zaangażowania, kwalifikacji zawodowych i ilości przepracowanych godzin. Co roku ustalana jest minimalna stawka godzinowa ${ }^{15}$.

W angielskim systemie penitencjarnym wszyscy więźniowie, którzy uczestniczą w celowych działaniach (praca, edukacja, szkolenia) muszą być wynagradzani. Według Prison Service Order 4460 Prisoners' Pay punkt 1.1 celem wynagradzania więźniów jest zachęcanie i nagradzanie ich konstruktywnego uczestnictwa w systemie zakładu. Nie może zatem działać jako czynnik zniechęcający. Wynagrodzenie, jako jeden z elementów w procesie motywowania więźniów, nie powinno być traktowane oddzielnie. Stawki wynagrodzenia mogą być zróżnicowane w zależności od środków, ilości i rodzaju pracy oraz przysługujących osadzonemu przywilejów ${ }^{16}$. Wydaje się, że celem takiego uregulowania jest przede wszystkim efektywna resocjalizacja skazanych.

W Stanach Zjednoczonych opracowuje się specjalną siatkę płac dla więźniów. Zarobione pieniądze są przekazywane na indywidualne konta. Środki te mogą zostać przeznaczone na spłatę zobowiązań, a jeżeli takowych nie ma, więzień może przeznaczyć je na zakupy w kantynie więziennej lub odłożyć na czas po zakończeniu wyroku ${ }^{17}$. Pozytywnie oceniam to, że zarobione pieniądze więźniowie przeznaczają najpierw na spłatę zobowiązań.

\section{Podsumowanie}

Zmiana art. 123 k.k.w. na skutek orzeczenia Trybunału Konstytucyjnego niewątpliwie odpowiada obecnie wymogom konstytucyjnym oraz tym, które są stawiane przez międzynarodowe dokumenty. Pociągnęła ona także za sobą praktyczny skutek - niestety w postaci spadku zatrudnienia odpłatnego. Pan Marcin Kunicki z Centralnego Zarządu Służby Więziennej wprost przyznaje, że skazani byli atrakcyjni dla pracodawców, kiedy można było im płacić połowę stawki. Od kiedy zaś ich zarobki muszą być na poziomie minimalnej pensji, pracodawcy nie są już tak chętni do ich zatrudniania ${ }^{18}$. Zgodnie $\mathrm{z}$ danymi statystycznymi udostępnionymi przez Służbę Więzienną, średnia płaca w roku 2014 wyniosła 1138,56 zł, a średnia stawka za godzinę 10,14 zł. W stosunku do ubiegłego roku więcej osób zostało

\footnotetext{
${ }^{15}$ Tamże, s. 71-72, 82.

${ }^{16}$ M. Muskała, Wykonywanie kary pozbawienia wolności $w$ angielskim systemie penitencjarnym, „Przegląd Więziennictwa Polskiego" 2012, nr 76-77, s. 319.

17 A. Barczykowska, System zakładów karnych i wykonywanie kary pozbawienia wolności $w$ Stanach Zjednoczonych Ameryki, „Przegląd Więziennictwa Polskiego” 2013, nr 79, s. 98.

${ }^{18}$ G. Zawadka, J. Ćwiek, Więzień do wzięcia, http://www.rp.pl/artykul/863623.html [dostęp: 28.02.2015 r.].
} 
zatrudnionych zarówno odpłatnie, jak i nieodpłatnie, jednakże jednocześnie zmalała liczba osadzonych $^{19}$.

\section{Bibliografia:}

\section{Literatura}

Barczykowska A., System zakładów karnych $i$ wykonywanie kary pozbawienia wolności w Stanach Zjednoczonych Ameryki, „Przegląd Więziennictwa Polskiego” 2013, nr 79

Dawidziuk E., Traktowanie osób pozbawionych wolności we wspótczesnej Polsce na tle standardów międzynarodowych, Warszawa 2013

Kalisz T., Zatrudnienie skazanych odbywajacych karę pozbawienia wolności, Wrocław 2004

Muskała M., Wykonywanie kary pozbawienia wolności $w$ angielskim systemie penitencjarnym, „Przegląd Więziennictwa Polskiego” 2012, nr 76-77

Stelina J., Gdańskie Studia Prawnicze. T. XXX. Wybrane zagadnienia prawa pracy i prawa socjalnego, Gdańsk 2013

\section{Pozostałe źródła}

Rekomendacja Komitetu Ministrów do państw członkowskich Rady Europy w sprawie Europejskich Reguł Więziennych przyjęta przez Komitet Ministrów w dniu 11 stycznia 2006 r. na 952 posiedzeniu delegatów, http://www.cossw.pl/file/redir.php?id=5853

Wyrok Trybunału Konstytucyjnego z dnia 23 lutego 2010 r., P 20/09 (Dz. U. z 2010 r. Nr 34, poz. 191)

Roczna informacja statystyczna za rok 2014, Ministerstwo Sprawiedliwości - Centralny Zarząd Służby Więziennej, http://sw.gov.pl/Data/Files/001c169lidz/rok-2014.pdf

Ćwiek J., Zawadka G., Więzień do wzięcia, http://www.rp.pl/artykul/863623.html

\footnotetext{
${ }^{19}$ http://sw.gov.pl/Data/Files/001c169lidz/rok-2014.pdf [dostęp: 31.03.2015 r.]
} 